\title{
Insurance Specific Risk and Profitability: Evidence from Nigerian Insurance Firms
}

\author{
Ibrahim Mallam Fali ${ }^{1, ~ *, ~ T e r z u n g w e ~ N y o r ~}{ }^{2}$, Lateef Olumide Mustapha ${ }^{2}$ \\ ${ }^{1}$ Department of Accounting, University of Calabar, Calabar, Nigeria \\ ${ }^{2}$ Department of Accounting and Management, Nigerian Defence Academy, Kaduna, Nigeria
}

Email address:

faliibrahim7@gmail.com (I. M. Fali), terzungwenyor@gmail.com (T. Nyor), midelat2009@gmail.com (L. O. Mustapha)

${ }^{*}$ Corresponding author

\section{To cite this article:}

Ibrahim Mallam Fali, Terzungwe Nyor, Lateef Olumide Mustapha. Insurance Specific Risk and Profitability: Evidence from Nigerian Insurance Firms. International Journal of Accounting, Finance and Risk Management. Vol. 5, No. 3, 2020, pp. 141-148. doi: $10.11648 /$ j.ijafrm.20200503.13

Received: June 4, 2020; Accepted: June 20, 2020; Published: July 4, 2020

\begin{abstract}
Insurance firms assume different types of business-specific risks that affect financial operations. The study therefore investigates the effect of these insurance specific risks on profitability in Nigeria over the 10-year period (2009-2018) with a sample size of 19 firms. Three variables, such as Re-insurance, Technical Provisions and Underwriting Risks, have been used as a measure of insurance specific risk for independent variables. The net profit margin was used as a measure of profitability for the dependent variable. The study is based on the Ex-Post Facto Research Design, which uses data already collected for the study. The study used secondary data from their annual reports. The results of the fixed effect regression model showed that the technical provision and the underwriting ricks had a negative and significant impact on profitability, while the re-insurance risk had a negative and insignificant impact on profitability. The study concludes that an increase in technical provision and risk underwriting will lead to a poor profitability of the insurance companies listed in Nigeria. The study recommends that insurance companies in Nigeria should make sufficient provision for outstanding claims by conducting an adequate assessment of their liabilities and also taking into account past experience to develop a comprehensive procedure for effectively monitoring and controlling their outstanding claims.
\end{abstract}

Keywords: Profitability, Re-insurance Risk, Technical Provision Risk and Underwriting Risk

\section{Introduction}

With the intention of gaining returns on its investment, each investor undertakes investment carefully. But one of a firm's key priorities is to make an income. Cash-backed income would allow management to allocate dividends to the owners [21]. He also states that profitability should better be calculated in terms of gross profit margin (GPM) net profit margin (NPM) for the period, revenue gain (ROA), earnings gain (ROE) and return on capital invested (ROCE). Profitability ratios measure the ability of the company to produce income and core revenue for financial analysis, creditors, and customers, and can also be considered as the main indicator of the company's overall performance. Profitability ratio analysis is essential to lenders, borrowers, prospective buyers, banks, and government alike as it lets them make decisions [29].

It is commonly accepted that a corporate organization's primary target is productivity (profitability). Thus, competitiveness is important to a company's sustainability and development as it dictates the ability of a company to manufacture and deliver quality products and services, to provide for workers by payment of salaries and other benefits, to satisfy investor (shareholder) demands and to fulfill social obligations [7]. A business is considered to be profitable if it receives enough income to offset its costs and expenditures; therefore, profit exists if the revenue earned by a business above or equals its expenditures [31]. Profitability serves as a metric of market performance, plays a central role in certain management decisions, and determines the capacity of a company to invest [12].

Insurance-specific risk refers to a danger that an insurance scheme protects that can trigger financial damages. When the 
covered incident happens and a lawsuit is filed, the insurance provider must pay the negotiated value of the refund to the policyholder, in this contents the insurance specific risk are re-insurance, technical provisions and underwriting risks.

Risk can also be referred to as the probabilities of partaking an unexpected or adverse outcome. Thus, any act or action that leads to loss of any type can be labeled as risk. There are different kinds of risks that a company might face and needs to stun. Risks can be categorized into three types namely: Business, Non-Business, and Financial Risks. Business Risk are taken by industry themselves in order to maximize investors' value and returns. Non- Business Risk are not under the control of companies. They are risks that arise out of political and economic instabilities. Financial Risk on the other hand is the risk that involves monetary harm to industries and mostly arises due to unpredictability and losses in the financial market which is caused by movements in stock prices, currencies, interest rates and so on. For the purpose of this research we adopts financial risk because it has some advantages over other types of risk. These include ease of calculation and commonly agreeable definition and can easily found in financial statement of a companies.

Financial risk, according to [26], is the risk at which the business institutions do not have adequate cash to use for their own obligations. It is a phrase used to describe a condition where a company does not keep enough cash to pay on time for products, banks and other parties. Financial instability can also be seen as the increased volatility in net cash flows to stock investors arising from the fixed financial commitment relating to debt finance and capital leasing [32].

Insurance specific risk is confirmed to be practical issues in Nigeria [6]. Some of the insurance firms that collapsed in Nigeria were due to the poor management of insurance specific financial risk and regulatory guidelines. For instance, Security Assurance plc (2008), Sun insurance plc (2008) and Investment and Allied insurance plc (2014). The collapse of insurance firms has led to a loss of equity among shareholders, a loss of employment among employees, and the government will no longer be taxed by those companies. [13], states that, there is a need for insurance companies to maintain an optional level of underwriting and claims management standards to prevent exposure to underwriting losses for improved financial performance. It is against this background that the study seek to study the effect of insurance specific risk on profitability of Nigerian insurance firms.

Previous empirical research on insurance specific financial risk and financial performance have presented conflicting result, others agreeing while some disagreeing with important theories of insurance specific financial risk across the world $[26,1]$. The contradictory results justify further research. To the best of the researchers' knowledge little studies have been carried out on insurance specific financial risk and hence, the need to do this study in Nigeria. Therefore, this study examine the effect of insurance specific risk on profitability of Nigerian insurance firms.
In view of the above, therefore, the following research hypothesis was developed and all are stated in null form.

$\mathrm{H}_{01} \mathrm{Re}$-insurance risk has no significant effect on financial performance of listed insurance companies in Nigeria.

$\mathrm{H}_{02}$ Technical provisions risk has no significant effect on financial performance of listed insurance companies in Nigeria.

$\mathrm{H}_{03}$ Underwriting risk has no significant influence on financial performance of listed insurance companies in Nigeria.

This work is positioned on the datum that most research works on the insurance specific financial risk and profitability are focused on the insurance sector in another country. By consequences, scholars have not paid sufficient attention to the insurance companies in Nigeria. The study would be significant in providing information to investors, government agencies, business professionals, accounting practitioners, regulators and the literature on insurance specific financial risk and profitability. The study covers a period of ten $(10)$ years $(2009-2018)$. To achieve this study, the paper is divided into five sections namely: section one is the introduction, section two takes up the literature review, section three presents the methodology, section four deals with results and discussions and section five conclude the study.

\section{Literature Review}

In this section, a review of extent literature on the subject matter is carried out covering conceptual issues, theoretical review and review of empirical studies.

\section{Conceptual Issues}

The conceptual issues focused on re-insurance risk, risk of technical provisions, underwriting risk and profitability that are the main focus of this study. For re-insurance risk, it is the risk that occurs when an insurance company suffers high claims beyond its ability to meet the obligations. Therefore, reinsurance is a process where an insurance firm agrees to insure another insurance firm against a portion or all losses that the reinsured may suffer [22]. Reinsurance is an agreement under which one insurance firm (the "reinsurer") agrees to pay another insurance company (the "reinsured," cedent "or" main "company) for all or part of the risks that the latter assumes under a contract or scheme imposed by the insurance provider [27].

Insurers, particularly broad insurers, frequently depend on their reinsurers for due repayment. The credit risk in the reinsurance portion can be significant in the midst of others, making it analytically necessary for insurers to implement structured processes about reinsurance choices. The use of reinsurance in capital control, the pacing of reinsurance premium disbursements and liquidity control entitlements, the connection between reinsurance system and pricing and underwriting management are among the considerations that must be addressed in the reinsurance risk management phase [28]. We adopt the measurement adopted by [33], which measured reinsurance risk as premium ceded over total asset. 
Technical Provisions Risk, in another hand, According to [19], there is a chance of inadequate technical provisions or unnecessary provisions being kept unjustifiably to satisfy the insurance commitments and to settle all potential claims with policyholders and other creditors arising over the duration of the insurer's insurance plan portfolio. Otherwise, a situation in which arrangements are set at a lower level than currently necessary may portray the financial condition of the company in a better light than it currently is. The probability of technical requirements is calculated by the protection ratio (outstanding claims to equity ratio) [33]. This might result in inappropriate underwriting decisions being made.

[11] Stated that a technological danger to insurance companies' solvency is definitely that of undervaluing technological provisions. This risk signals the companies' inability of meeting their commitments against the insured and the claimants because of insufficient contractual arrangements. Therefore, the possibility of insufficient technical provisions should be expected by all companies by following prudential (this word should be taken in relation to the exact and detailed approaches to computing technical provisions listed in the report) measurement procedures and approaches when defining the provisions, and by supervisory bodies. The risk of technical provisions is determined by the safety ratio (claims outstanding in relation to equity ratio) and defined as a risk of inadequate technical provisions or unjustifiably excessive provisions. Benefit of legal provision is that the responsibility of the company to the policyholders may be understated. Obviously, from the viewpoint of financial stability and soundness, the issue is with potential understatement of responsibility, as any such understatement will result in the insurer being unable to meet all its responsibilities to the insured [28].

Underwriting risk is the one of the financial risk faced by insurance firms where the cost incurred to cover a claim may exceed total premium paid [26] and in another word underwriting risk is the risk that the premiums collected will not be sufficient to cover the cost of coverage being undertaken by the underwriter. Underwriters assess the risk and experiences of prospective clients. Underwriter decide how much coverage the client should get, how much they should pay for it, or whether even to take the risk and insure them, in work of [4] cited by [33]. Underwriting involves a quantifying risk exposure and defining the premium that desires to be charged to insure that risk. Underwriting risk is a possibility that the premiums pooled by the insurance firms may not be enough in cost coverage [10]. The role of the underwriter is to safeguard the firm's book of trade from risks that they feel will make a loss and issue insurance procedures at a premium that is commensurate with the exposure presented by a risk [33].

[18] Said the insurance company's market operation exposes it to risk underwriting. The risk in every insurance policy is that there will be a covered incident and an unintentional sum in potential damages. Underwriting risk is chance and thus changeable by the definition of insurance contracts, which relates to insurance volatility. The insurance arrangement is a civil agreement in which the policyholder agrees to pay the insurance premium, and in the case of an insured incident, the insurer takes the responsibility to pay costs. According to [1], underwriting risk may be created primarily from the insufficiency of the premiums in the form of underestimation of the premiums or inadequate diversification of the insurance portfolio.

\section{Profitability}

Profitability is the ability to profit from all a company's operations, and to gain a return on investment. It also shows how efficiently the management can make profit by using all the resources available at its disposal ([15] cited by [35]. Put in another way, in [9] cited by [35] viewed profitability as the ability to create an excess of revenue over expenses in order to attract and hold investment capital. Four usual measures of firm's profitability are: operating profit margin, net profit margin, return on assets and return on equity. The term profitability is not synonymous with the term efficiency. Profitability is a performance metric that is considered a reference to productivity that improvement steps for greater efficiency. Often adequate benefits can label inefficiency and, conversely, lack of benefit can reflect a reasonable degree of efficiency. The net profit figure simply reveals a satisfactory balance between the values receive and value given [14].

Review of Empirical Studies

[3], studied the determinants of the financial performance of Romanian insurance firms. From 2008 to 2012 the report hired 21 businesses. Risk dependency on reinsurance insurance. Financial efficiency of the insurance firms has been calculated by the yield on total asset ratio. The analysis shows that the reinsurance risk has a positive correlation on the return on the total asset ratio while the underwriting risk has a negative impact on the return on the total asset ratio and has major connections with the financial output of the insurers. The study establishes a methodological awareness gap as it reflects on the possibility of reinsurance in Romania while the present study explores possibility in Nigeria.

[26] Studied the effect of financial risks on the financial performance of insurance companies listed at Nairobi Securities Exchange. The study used a sample of six (6) insurance companies covering the period of six (6) years, 2012-2017 was taken. The study used quantifiable secondary data which was analyzed using descriptive and inferential statistics on SPSS version 22. The study found that reinsurance risk positively related to ROA but had insignificant effect and underwriting risk negatively and insignificant effect ROA.

[33] Studied the effect of the financial risk on insurance carriers' success in Ethiopia. For the duration of sixteen (16) years, 2000 to 2015, a selection of eight (8) listed insurance firms was chosen. The thesis used a mixed-method approach to science by integrating documentary documentation with unstructured in-depth interviews. Panel simulation methods were introduced, fixed effect model regression analysis was used, and applications with E-view8 was used. The study finds that reinsurance risk has a negative and significant impact on the performance of insurance companies at $5 \%$, 
technical requirements risk has a negative and significant effect on the performance of insurance companies in Ethiopia at $1 \%$ and $5 \%$, whereas the underwriting risk has a negative and significant effect at $1 \%$ and $5 \%$ indicates.

[34] Carried out a study into the determinants of the competitiveness of insurance firms in Ethiopia. The study used a mixed analysis approach to realize the goal. For nine insurance companies from the total population of all insurance companies licensed by NBE and under service in Ethiopia, panel data covering the eleven-year period from 2004 to 2014 were analyzed. An in-depth interview with the business executives was also held. The study's results found that technological provision has statistically significant and negative relationship with insurers' profitability while the result reveals that underwriting risk have significant and negative effect on insurers' profitability in Ethiopia. The study creates a conceptual knowledge gap because it focused on technical provisions risk in Ethiopia while the current study is looking at technical provisions risk in Nigeria.

In Kenya, [25] performed a study on determinants of the financial performance of insurance firms. All 23 general insurance companies in Kenya were interested in the report. The data were collected from insurance companies listed and the sample size of 22 general insurance companies. One company was dropped from the survey because it was put at the time of the test under the receivership. Secondary data were used for four (4) years from 2009-2012 and a multiple regression analysis technique was utilized in the study. The study did not consider a relationship between results and underwriting risk on the basis of the tests, which indicates that underwriting risk did not substantially affect financial performance.

[4] Conducted research in the Indian insurance industry on the connection between financial risk and financial performance. The research employed 24 life insurance firms that served as a target demographic in the Indian insurance industry. Eight life insurance firms all belonging to the private sector were chosen from this. They used secondary data points from the listed insurance providers' annual reports. To evaluate the factors affecting financial results in the Indian insurance industry over the 2005/06-2012/13 period. Many regression model findings show that underwriting failure has a negative effect but has no substantial impact on financial performance.

[16] Studied the competitiveness of macroeconomics and insurance companies: a post-crisis situation in Pakistan. Profitability was the dependent variables and the independent variable underwriting the risk. His observation was that liability underwriting is objectively a significant determinant of insurance insurers' profitability. Relative loss underwriting has a negative effect on life insurance sector productivity.

Modern Portfolio Theory Review

[24] Founded Modern Portfolio Theory (MPT) in 1952 and endorsed and cited $[5,23,30]$, etc. The hypothesis suggests that an investor could potentially increase his projected return while reducing risk volatility by investing in a diversified asset portfolio that had various price fluctuations in a given market. Modern theory of portfolios split the risk into two sections, respectively systemic and unsystematic. Systematic instability is considered to occur within companies or on the market as an intrinsic instability. Unsystematic risk is the idiosyncratic danger that occurs for a specific security project, which can be reduced or eradicated by certain major risk management which diversification approaches. An important conclusion of MPT is that by diversification one can lower the unsystematic risk. Research have showed you only need a total of 20 shares to diversify a portfolio considerably [5]. If financial risk is diversifiable or not, according to MPT, it's all dependent on its determinants. This implies that insurance company governance system cannot eradicate macroeconomic variable-determined risk by diversifying portfolio within the market. As a consequence, risk due to unsystematic factors which are also referred to in this analysis as microeconomic factors can be well diversified by sector lending. The factors of analysis are related to the theory of portfolios.

\section{Methodology}

The study adopts the Ex-Post Facto Research Design, which uses data already collected for the study. The population of the study consists of the twenty seven (27) insurance companies listed on the floor of Nigerian Stock Exchange as at 31st December, 2018. The use of listed insurance companies is based on availability and reliability of their financial data. In order to arrive at a sample for the study all insurance companies listed after 2009 were excluded and the insurance companies that the researchers was not able to gather all the necessary information for the period of the study (2009 to 2018). After applying the above filters nineteen (19) of the listed insurance companies formed the study sample. 5 .

To achieve the stated research objective, the study employed panel data from secondary sources which are quantitative in nature. The data were obtained from the annual reports of individual insurance companies submitted to the Nigerian Stock Exchange. The technique of data analysis employed in this study is the multiple regression analysis. The study adopted this technique to ascertain the effect of the insurance specific financial risk (reinsurance risk, technical provisions risk and underwriting risk) on profitability. The study used two control variables namely: firm age and leverage. Profitability of listed insurance companies in Nigeria which is measured by Net profit margin (NPM). The data was analyzed using STATA 13 statistical package, and the outcome was used to test the hypothesis formulated for the study after conducting necessary tests. Various robustness tests such as test for multicollinearity between the independent variables were carried out to improve the validity of the results obtained.

Profitability of insurance companies is estimated using Net profit margin (NPM) as its proxy.

Profitability which is measured by NPM, is a function of three explanatory variables, namely: reinsurance risk (RIR), 
technical provisions risk (TPR) and underwriting risk (UR). Control variables are firm age (FAGE) and leverage (LEV). Hence;

\section{$\mathrm{NPM}=\mathrm{f}(\mathrm{RIR}, \mathrm{TPR}, \mathrm{UR}, \mathrm{FAG}, \mathrm{LEV})$}

The Ordinary Least Square (OLS) regression model was used to estimate the effect of the explanatory variables on the explained variable. The $[8,26,33]$ model was adopted with modifications. The model is given below:

$$
\begin{gathered}
\mathrm{NPM}_{\mathrm{it}}=\beta 0+\beta 1 \mathrm{RIR}_{\mathrm{it}}+\beta 2 \mathrm{TPR}_{\mathrm{it}}+\beta 3 \mathrm{UR}_{\mathrm{it}}+\beta 4 \mathrm{FAG}_{\mathrm{it}}+ \\
\beta 5 \mathrm{LEV}_{\text {it }}+\mathrm{e}_{\mathrm{it}}
\end{gathered}
$$

Where:

$\beta 0, \beta 1, \beta 2, \beta 3 \ldots \ldots \ldots \ldots \ldots . . . . . . .35$ are parameters to be estimated with a priori expectation.

Net profit margin, measured as Net income to Total revenue [7, 2], reinsurance risk, measured as premium income to total asset $[33,26,4]$, technical provisions risk, measured as claim outstanding to total equity [33, 4], underwriting risk, measured as loss or claim incurred to premium earned [33, 4], firm age, measured as age of the company since incorporation [17] and leverage, measured as ratio of total liabilities to total assets $[20,36]$.

$$
\begin{aligned}
& \beta 0=\text { Constant } \\
& e=\text { Error term }
\end{aligned}
$$

\section{Results and Discussion}

The results obtained from the descriptive are presented in this section, starting with descriptive statistics.

Table 1. Descriptive Statistic.

\begin{tabular}{llllll}
\hline Variable & No of obs & Mean & Std deviation & Min & Max \\
\hline ROA & 190 & .020 & .42 & -4.62 & 1.04 \\
RIR & 190 & .32 & .19 & .06 & 1.17 \\
TPR & 190 & .14 & .14 & -.19 & .70 \\
UR & 190 & .37 & .25 & .06 & 2.06 \\
LEV & 190 & .43 & .21 & .02 & 1.08 \\
FAG & 190 & 14.34 & 8.64 & 1 & 29 \\
\hline
\end{tabular}

Source: Descriptive Statistics Result using STATA 13: Researcher (2020).

Table 1 shows description on the variables based on the measurement used. The net profit margin reveals an average value of $2 \%$ and a standard deviation of $42 \%$ indicating that the sampled firms are widely spread out from the mean. The table further reveals that ROA has a minimum loss return on asset of $462 \%$ and the highest recorded net profit margin as $104 \%$.

With respect to re- insurance risk, table 1 reveals that the average value and standard deviation to be .32 and .19. This shows that re-insurance risk of the insurance firms in Nigeria has low dispersion from the means as suggested by the standard deviation. It further reveals that insurance firms in Nigeria follows similar pattern in term of risk associated with reinsurance. The table further indicates that the highest value and the lowest value of re-insurance risk is .06 and 1.17 respectively.

The table also further reveals that technical provision risk has an average value of .14 and a standard deviation of .14 revealing a low wide dispersion on these variables from the mean. The mean suggests that about $14 \%$ of the sampled insurance firms' equity covers for outstanding claim. The minimum value and maximum value of technical provision risk is revealed as -.19 and .70. Further, the table also shows that the mean value of underwriting risk to be .37 with a standard deviation of .25 this suggest that there is a low disparity of the data from the mean. The minimum and the maximum value of UR is 0.06 and 2.06.

Finally, the control variable has a mean value of .43 and a standard deviation of .21 . This reveals that the individual leverage of the firm is not widely spread out from the mean, thus is closely cluster around the mean. The mean values of .43 further suggests that the level of in the firms are not so high. The table also reveals the minimum value and maximum value to be .02 and 1.08 respectively. The finally variable firm age reveals an average value of 14years incorporation with a standard deviation of 9 years.

Diagnostic Test

For better validity of all statistical inferences to be drawn from the study, this part presents the result of diagnostic test conducted. The diagnostic test included test for normality of the residual, multicollinearity test, heteroscedasticity test.

Table 2. Diagnostic Check.

\begin{tabular}{lll}
\hline Variables & VIF & Tolerance value \\
\hline RIR & 1.11 & 0.90 \\
TPR & 1.19 & 0.84 \\
UR & 1.09 & 0.92 \\
LEV & 1.12 & 0.89 \\
FAG & 1.11 & 0.90 \\
Other Tests & Chi square & P-value \\
Normality of residual & & 0.000 \\
Heteroscedasticity & 1335.07 & 0.000 \\
Auto serial correlation & 13.93 & 0.001 \\
\hline
\end{tabular}

Source: STATA 13: Researcher (2020).

The classical assumption of OLS regression model is that the explanatory variables are not perfectly correlated (absence of multicollinearity). According to Gujarati (2004) Tolerance less than 0.1 and the VIF value 10 and above imply the presence of multicollinearity in the estimates. However, the results from Table 2 proved that there is no existence of excessive correlation among the independent variables, because the smallest tolerance value (TV) is 0.84 , while the highest variance inflation factor (VIF) is 1.19.

One the assumption of ordinary least square regression is the normality of data and residual. The normality individual data was tested using Jacque Bera tests at 5\% level of significant. The results in table 2 above shows that the chi square is significant with a p-value of 0.000 which suggest that the residual is not normally distributed.

Heteroscedasticity test was carried out to check the homoscedasticity assumption of a regression model. To test for the existence of heteroskedasticity, this study uses the Breusch- Pagan or cook - Weisberg to conducts the test and the result reveals that $\mathrm{chi}^{2}$ is 1335.07 and the prob $>\mathrm{chi}^{2}$ is 
0.000 which is significant at less than $5 \%$ level of significance. This reveals the presence of the effects of heteroskedasticity.

Also, serial/ auto correlation test was conducted using Wooldridge test for autocorrelation in panel data. The test reveals a chi square of 13.93 and a p-value of 0.001 which is significant at $5 \%$ level of significance. Hence the study concluded that there is presence of auto correlation in the study.

Table 3. Panel Analysis Test.

\begin{tabular}{lll}
\hline Tests & Chi square & P-value \\
\hline Hausman specification test & 802.42 & 0.000 \\
\hline
\end{tabular}

Source: STATA 13: Researcher (2020).

Due to panel nature of the data, panel analysis was conducted using hausman specification test to make decision relation to choosing fixed model or random effect model. The result shows that at $5 \%$ level of significance, the $\mathrm{chi}^{2}$ is 802.42 and the prob $>$ chi $^{2}$ is 0.0 .000 which is significant indicating that Hausman test selects fixed effect regression as ideal. The study interprets the regression with cluster or robust standard error of fixed effect model to deal with problem of heteroskedasticity, serial (auto) correlation and non-normality data.

The Regression Result

This table presents the regression result of insurance specific risk variables and profitability of listed Nigerian insurance firms.

Table 4. Robust fixed effect Regression Analysis.

\begin{tabular}{lllll}
\hline Variables & Coeffcient & Std error & T-value & P-value \\
\hline RIR & .27 & .36 & 0.73 & 0.472 \\
TPR & -.62 & .24 & -2.52 & $0.021^{* *}$ \\
UR & -.052 & .013 & -4.16 & $0.001^{* *}$ \\
LEV & .44 & .22 & 2.02 & $0.058^{*}$ \\
FAG & -1.23 & 1.081 & -1.14 & 0.270 \\
Constant & -1.29 & 104 & 1.23 & 0.235 \\
R $^{2}$ within & 0.25 & & & \\
F-statistic & 6.41 & & & $0.001^{* *}$ \\
\hline
\end{tabular}

**,*significant at 5\%,10\%.

Source: R. OLS regression result using STATA 13.

\section{Interpretation}

The table 4 above presents fixed effect regression result chosen for the study. $\mathrm{R}^{2}$ within reveals a value of .25 indicating that the risk proxies (re-insurance risk, technical provision risk and underwriting risk) are able to explain $25 \%$ of variations in return on asset of the listed insurance firms while the remaining percentage is explained by other factors not captured in the model. The F-statistic is 6.41 with a pvalue of 0.001 which reveals that the model is fitted at less than 5\% significant level and the proxies of insurance specific risk have joint effect on profitability of listed insurance firms in Nigeria.

Discussion of findings

Table 4 reveals that RIR has a coefficient of .27 and a probability value of 0.472 which is not significant at $5 \%$ level of significance. This finding shows that any increase or decrease in the risk associated with re-insurance will not affect profitability of listed insurance firms, in line with [26, 33] and contrary to [3] who found that re-insurance risk enhance the financial performance of insurance firms in Romania. The result is conforms to the apriori expectations which predicted a negative relationship between re-insurance risk and profitability (ROA) and also in line with portfolio theory although it is not significant.

Technical provisions risk has a negative coefficient of -.62 and a p-value of 0.021 which is significant at $5 \%$ level of significance. The finding implies that any increase in technical provision risk will reduce return on asset of the sampled firms by $62 \%$. This negative effect suggests that when the insurance companies are faced with more risk associated with technical provision it will reduce the profitability measured by net profit margin.

The findings suggests that when the insurance firms hold insufficient technical provision for outstanding claim, the financial performance of the insurance firms reduces. Thus understating liabilities may lead to insurance company's inability to settle their obligations. This finding is also in line with the apriori expectation of the study and the portfolio theory. It also corroborates with the studies of $[33,34]$ who also found that technical provision risk has inverse influence on profitability (ROA).

Underwriting risk has a negative and significant influence on profitability (NPM) as reveals by the coefficient of -.052 and a p-value of 0.001 which is significant at $5 \%$ level of significance. The finding implies that any increase in the underwriting risk face by these insurance companies will decrease profitability by $5.2 \%$. Hence the percentage increase in underwriting risk will have inverse effect on profitability of listed insurance companies in Nigeria. This finding provide evidence that when loss or claim incurred increase against premium earned, the insurance firm may not get enough revenue from premium that can take care of claims. Thus, the insurance firms may lose earnings that could result in decrease in profitability. This finding is consist with the apriori expectation of the study and in line with portfolio theory and consistent with findings of $[33,34,16,3]$ and so forth who found out that increase in underwriting risk will reduces profitability (NPM). It is also contrary to [26, 4, 25] who found that underwriting risk does not affect profitability (ROA).

\section{Conclusion and Recommendations}

This study investigate the effect of insurance specific risk on profitability of listed insurance companies in Nigeria for the period 2009 to 2018. The study discovered that technical provision risk and underwriting risk have negative and significant effect on return on asset of the listed insurance firms in Nigeria. The study found that re-insurance risk, has negative and insignificant effect on return on asset of the listed insurance companies in Nigeria. The study concludes that increase in technical provision risk will lead to poor profitability of the insurance firms in Nigeria and also that 
increase in underwriting risk will cause a reduction in financial performance of the insurance firms in Nigeria. The study recommends that, Insurance companies in Nigeria should do more in holding sufficient provision for outstanding claims by carry out adequate assessment on their liabilities and also taking into cognizance past experience to develop a comprehensive procedure to effectively monitor and control their outstanding claim. The study also recommends that, regulatory body (NAICOM) should include technical provisions risk as part of insurance companies risk indicators index, and Nigerian insurance companies should do their best in minimizing cost and claims by engaging expertise in valuation that will estimate prices proper.

\section{References}

[1] Adrian, R. (2014). The relationship between financial risk and financial performance insurance companies in Kenya. Unpublished Master's Thesis. University of Nairobi.

[2] Al Omari, R., Warrad, L., \& Al Nimer, M. (2015). Sectorwise effect of solvency on profitability: Evidence from Jordanian Context. Journal of Economic and Sustainable Development, 6 (5), 46-56.

[3] Ana-Maria, B., \& Ghiorghe, B. (2014). The determinants of financial performance in the Romanian Insurance Market. International Journal of Academic Research in Accounting, Finance and Management Sciences, 4 (1), 300-308.

[4] Arif, A., \& Showket, A. (2015). Relationship between financial risk and financial performance: An Insight of Indian Insurance Industry. International Journal of Science and Research, 4 (11), 1424-1433.

[5] Damalie, S. N. (2018). Student-teachers' experiences of microteaching on an economics methods course. African Research Review, 12 (2), 101-108.

[6] Deloitte. (2014). Deloitte Insurance Risk Management Survey: State of the Industry. Lagos.

[7] Eke G. O., Akpanuko E. E., \& Umoffong J. N. (2019). Corporate governance and profitability of quoted oil and gas companies in Nigeria. International Journal of Business and Management Review, 7 (8), 88-115.

[8] Fali, I. M., Nyor, T, \& Mustapha L. O., (2020). Financial risk and financial performance of listed insurance companies in Nigeria. European Journal of Business and Management, 12 (12), 143-153.

[9] Eljelly, A. (2004). Liquidity- profitability trade-off: An empirical investigation in an emerging market. International Journal of Commerce and Management, 14 (2), 48-61.

[10] Ernst \& Young (2010). Analysis and valuation of insurance companies. Center for Excellence in Accounting \& Security Analysis, Columbia Business School.

[11] Giovanni, M. (2001). Technical provisions in non-life insurance. Conference of the insurance supervisory authorities of the member states of the European Union.

[12] Glautier, M., Underdown, B. \& Morris, D. (2011). Accounting Theory and Practice. Pearson.
[13] Holton, G. (2004). Defining Risk. Financial Analysts Journal, $60(6), 19-25$.

[14] Ibrahim, K. M., Stephen, I. O., Adah, A., \& Haruna, R. A. (2018). Corporate social responsibility and profitability of listed oil and gas firms in Nigeria. Journal of Accounting and Management, 1 (2), 148-154.

[15] Ifeoma, M., Innocent, C., \& Okelue, D. (2012). Financial management as a determinant of profitability: A study of selected pharmaceutical firms in Nigeria. European Journal of Business Management, 4 (20), 28-37.

[16] Ijaz, H. (2015). Macro economy and profitability of insurance companies: a post crisis scenario in Pakistan. Pakistan business review, 243-263.

[17] Ilaboya, O. J., \& Ohiokha, I. F. (2016). Firm age, size and profitability dynamics: a test of learning by doing and structural inertia hypotheses. Business and Management Research, 5 (1), 29-39.

[18] Jakovcevic, D., \& Mihelja, M. (2014). Underwriting risks as determinants of insurance cycles: case of Croatia. International Journal of Social, Behavioral, 8 (5), 1251-1258.

[19] Jasmina, S. (2003). Actuarial estimation of technical provisions adequacy in life insurance companies. School of Economics and Business in Sarajevo, Bosnia and Herzegovina, 523-533.

[20] Kazeem, H. S. (2015). Firm specific characteristics and financial performance of listed insurance firms in Nigeria: Unpublished M. Sc Dissertation.

[21] Kurawa, J. M. (2009): Evaluation of the Impact of Liquidity on the Profitability of Banks in Nigeria. Research journal of Business Management, 2 (2), 54-57

[22] Lee, H. (2012). An analysis of reinsurance and firm performance, Evidence from the Taiwan property-liability insurance industry.

[23] Makori, N. W. (2018). Credit risk management and level of non-performing loans in commercial banks in kenya.

[24] Markowitz, H., (1952). Portfolio selection, Journal of Finance, 7 (1), 77-91.

[25] Mirie, M. (2015). Determinants of financial performance in general insurance companies in Kenya. European Scientific Journal, 11 (1), 288-297.

[26] Mukino M. A. (2018). Effect of financial risks on the financial performance of listed insurance companies at Nairobi securities exchange. Unpublished Master's thesis. University of Nairobi.

[27] Munich (Re), (2010). Reinsurance: a basic guide to facultative and treaty reinsurance.

[28] National Bank of Ethiopia (NBE), (2010). Draft paper for risk grading rate insurance companies in Ethiopia.

[29] Nishanthini, A., \& Nimalathasan, B. (2013). Determinants of profitability: A case study of listed manufacturing companies in Sri Lanka.

[30] Nyasaka, F. O. (2017). The Relationship between Credit Risk Management Practices and Non-Performing Loans in Kenyan Commercial Banks: A Case Study of KCB Group Limited (Doctoral dissertation, United States International UniversityAfrica). 
[31] Pandey, I. M. (2010). Financial Management. Vikas Publishing House PVT Ltd, New Delhi, 595.

[32] Schweiss, K. (2017). An Analysis of Financial Risk Measures within Agricultural Cooperatives (Doctoral dissertation, North Dakota State University).

[33] Sisay, D. (2017). The Effect of financial risk on performance of insurance companies. Unpublished doctoral thesis. Addis Ababa University, Ethiopia.

[34] Suheyli, R. (2015). Determinants of profitability on insurance companies in Ethiopia. Unpublished Master's Thesis. Addis Ababa University.

[35] Sulaiman, A. S., Abubakar, A., \& Mohammed, M. U. (2018). Corporate social responsibility and profitability of listed oil and gas firms in Nigeria. Journal of Accounting and Management, 1 (2), 148-154.

[36] Sumaira, B., \& Amjad, T. (2013). Determinants of profitability panel data evidence from insurance sector of Pakistan. Elixir Financial Management International Journal, Pakistan. 